\title{
INFLUENCE OF HOUSEHOLD SOCIO-DEMOGRAPHIC CHARACTERISTICS ON FOOD SECURITY STATUS OF SMALL- HOLDER FARMERS IN UASIN GISHU COUNTY, KENYA
}

\author{
${ }^{1}$ Toroitich, Caroline, ${ }^{1 *}$ Mugalavai Violet, \& ${ }^{1}$ Ochuodho Julius \\ ${ }^{1}$ School of Agriculture \& Biotechnology, University of Eldoret, Kenya \\ *Corresponding author
}

DOI: 10.46609/IJAER.2020.v06i02.012 URL: https://doi.org/10.46609/IJAER.2020.v06i02.012

\begin{abstract}
Food security is important to economic, social, religious, political and cultural development. The study assessed the effect of household characteristics on food security status among smallholder farming households in Uasin Gishu County. Descriptive survey was adopted for the study and data was analyzed using descriptive statistics and logistic regression. Majority of respondents were male $(56 \%)$, with an average age of 38 years and most of them (78\%) married. One hundred and seventy-one $(43 \%)$ respondents had secondary school as their highest level of education. In relation to gender of head of households, the majority were led by men, at $78 \%$. A large proportion of the households $(67 \%)$ had farm size below five acres with average farm size reported to be 2.29 acres. Majority, $91 \%$, of the respondents owned the land with only $9 \%$ indicating that they leased land. Majority, $69 \%$ had more than six years farming experience. Majority of respondents sourced their food from own farm production at 96.9\%. Majority (70\%) of respondents had not experienced food insecurity.

There was insignificant ( $\mathrm{p}$-values>0.05) positive relationship between demographic characteristics and food shortage while gender variable shows inverse relationships. The odds of male headed household to experience food insecurity decreases by $1.9 \%$ compared to their female headed counterparts, $(\beta=-0.019)$. The odds for the married head of household to experience food shortages is 0.39 compared to single, widowed, separated combined $(\beta=0.390)$. The odds that those who are illiterate to be exposed to food insecurity is 0.121 as compared to those with some level of education $(\beta=-0.121)$. Furthermore, the odds to experience food shortages for those with less than two acres of land is 0.233 as compared to those with greater than two acres, $(\beta=0.233)$. In conclusion, demographic characteristics like gender, marital status, education level and size of farm influence the state of household food security.
\end{abstract}


International Journal of Agriculture and Environmental Research

ISSN: 2455-6939

Volume: 06, Issue: 02 "March-April 2020"

Keywords: household, food security, socio-demographic characteristics, smallholder farmers

\section{INTRODUCTION}

Food security is defined as a situation in which all people, at all at times, have physical, social and economic access to enough, safe and nutritious food which meets their dietary needs and food preferences for an active and healthy life (FAO, 2003). Apart from availability of food, there are other equally fundamental dimensions of food security such as access to and utilization of food, agricultural supply and productivity (Burchi \& Muro, 2015). Chronic food security is when a person is continuously unable to secure enough food. During transitory food insecurity period, a household adopt several coping strategies, including depletion of productive assets, mainly common in poor households; which may lead to chronic food insecurity in the longer term (Niles \& Brown, 2017). Food insecurity is a threat to the sustainability of livelihoods of smallholder farmers all over the world (Jensen, 2016). Ability of smallholder farmers to ensure consistent food security is influenced by socio-economic and climatic factors such as agricultural management of farming system, social capital of household, gender composition, gender of household head, education level of household head, size of household farm, land ownership, farming experience among others (Chege et al., 2016; FAO, 2003). In a study done in Ghana, $60 \%$ of the community members of Sekyere-Afram plains district were reported to be food insecure (Mensah et al., 2018). Misselhorn, (2005) reported that 58\% of households in Limpopo, South Africa were food insecure. In Kenya, Wachira, (2014) reported that 23\% of households were likely to face chronic food insecurity. Similarly, the $68 \%$ of households at the Coastal Kenya were found to be food insecure (GoK, 2010). This was attributed to high population density, diminishing food resources and household socioeconomic and demographic factors.

Globally, there are approximately 1.5 billion smallholder farmers, a figure that includes $75 \%$ of the world's poorest people (Lowder, Skoet, \& Raney, 2016). Most people living in extreme poverty depend on agriculture for their livelihoods. These smallholder and marginal farmers provide approximately $80 \%$ of the food in many developing countries, and even more in South Asia and Sub-Saharan Africa (Murphy, 2012). Despite this fact, these farmers tend to be underresourced and lacking access to improved inputs, rural services and markets, leading to low productivity and a lack of opportunity to break the cycle of poverty (Brown, 2015). Smallholder farmers have often been left out in policy making on the future of agriculture (Wiggins, Argwings-kodhek, Leavy, \& Poulton, 2011; Vorley \& Chan, 2012).

Kenya is a developing country whose $45 \%$ of GDP is contributed by the agricultural sector (Wachira, 2013). This sector is largely influenced by weather conditions and it's characterized by subsistence farming with little surplus output which puts vulnerable households at risk of starvation (Kumba, 2015). In Kenya, over 63\% of the total agricultural output is produced by 
International Journal of Agriculture and Environmental Research

ISSN: 2455-6939

Volume: 06, Issue: 02 "March-April 2020"

smallholder farmers with average farm sizes of about $0.47 \mathrm{ha}$. The farms provide food for homeconsumption and for the market (Rapsomanikis, 2015). Chagomoka, Unger, Drescher, Glaser, \& Marschner, (2016) asserted that individual community members willingness, property rights on resources and community level collective action are key to improvement of food security. Khalid, Schilizzi, \& Pandit, (2012) reported that demographic variables, water harvesting ability, knowledge \& information sources, awareness and attitude also influence food security status among the smallholder farming community members. In a study that linked household food security with age of household head, household size, education level and marital statuus, in Kilifi County, $80 \%$ of households were reported to be food insecure (Chege et al., 2016). The study further reported that elders were $1 \%$ food secure while adults were $40 \%$ food secure. Also, households with $\leq 2$ members were $10 \%$ food secure while households with $>10$ members were $2 \%$ food secure. A similar study in Kamkunji estate, Uasin Gishu County reported that womenheaded households were food secure more than men-headed households, as women would wake up very early in search of a day's work in order to get money for food (Tioko, 2015).

Many studies have been done in Uasin Gishu County on food security but very few have focused on Soy and Turbo sub-counties. Therefore, the purpose of this study was to evaluate the influence of socio-demographic characteristics of smallholder farmers on their household food security status. Findings from the study adds to the existing knowledge on food security determinants and helps smallholder farmers improve their food security status.

\section{RESEARCH MATERIALS AND METHODS}

\subsection{The study area}

The study took place in Uasin Gishu County because it is one of the high agricultural potential counties in Kenya. It borders Trans Nzoia County to the North, Elgeyo Marakwet County to the East, Baringo County to the South East, Kericho County to the South, Nandi County to the South West and Kakamega County to the North West. It lies between longitudes $34^{\circ} 50^{\prime}$ East and $35^{\circ}$ 37' West and latitudes $0^{\circ} 03^{\prime}$ 'South and $0^{\circ} 55^{\prime}$ 'North. It has a total area of 3,345.2 Sq. Km. Eldoret town is the county's headquarters. The County is made up of six sub-County and six constituencies: Turbo, Soy, Ainabkoi, Moiben, Kessess and Kapseret. For this study, Soy and Turbo sub-counties were considered. 


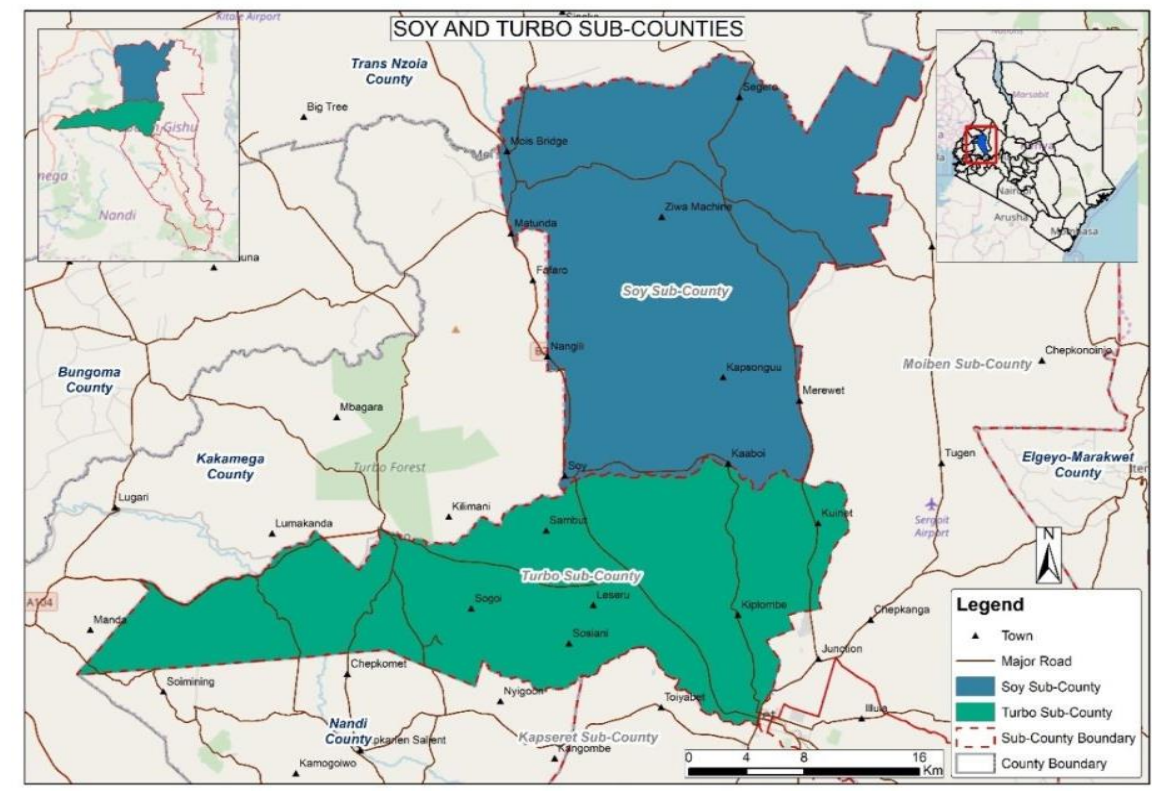

Figure 1: Study area showing Soy and Turbo sub-counties

\subsection{Research design}

A non-experimental descriptive survey design was used. The design involved a survey of key variables guided by the study objectives. Households were used as the basic units of analysis because it is in the households that farming, and food consumption decisions are made. It involved interviewing and using questionnaires to collect data from individuals of the households.

\subsection{Sample size and Sampling procedure}

\subsubsection{Sample size}

Two sub-counties, Soy and Turbo, were selected purposively and they had 30,018 smallholder farming households. A random sample of 397 households were selected and interviewed, 201 from Turbo and 196 from Soy sub-Counties. Cochran's formula was used to determine the sample size, as it is considered appropriate with large population.

$$
n_{0}=\frac{Z^{2} p q}{e^{2}}
$$

Where: 
- $\mathrm{e}=$ desired level of precision (margin of error 5\%)

- $\mathrm{p}=$ (estimated) proportion of the population which has the attribute in question (50\%)

- $\mathrm{q}$ is $1-\mathrm{p}$.

Using the confidence level of $\left.95 \%\left((1.96)^{2}(0.5) 90.5\right)\right) /(0.05)^{2}$ we get a minimum of 385 .

A random sample of 397 respondent households was interviewed.

\subsubsection{Sampling procedure}

Multistage purposive and simple random sampling was used. In the first stage, Uasin Gishu County was selected purposively. In the second stage, Turbo and Soy sub-counties were purposively selected since they had high number of small holder farmers. The third stage involved purposive selection of wards, namely: Sugoi, Kaptebee and Ngenyilel in Turbo Sub County and Soy, Kipsomba and Barsombe in Soy Sub County, as shown in figure 2 below.

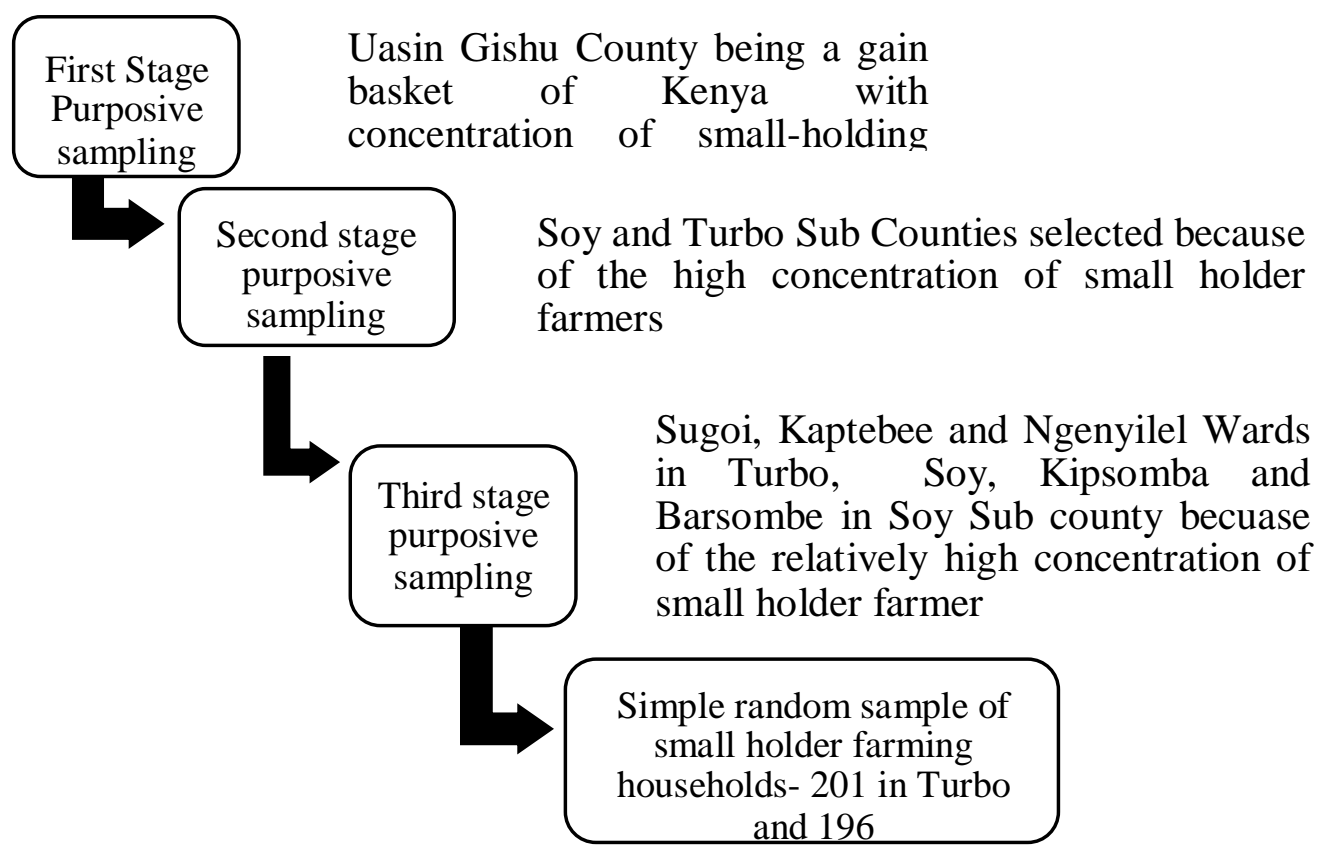

Figure 2: Multistage sampling procedure used in the study

\subsection{Data collection}

Interview schedules and questionnaires were used to collect both quantitative and qualitative data. The questionnaires were used because of its potential to reach many respondents within a short period of time and interviews provided a sense of confidentiality to the respondents. The 
International Journal of Agriculture and Environmental Research

ISSN: $2455-6939$

Volume: 06, Issue: 02 "March-April 2020"

questionnaires were designed in English language but administered in Kalenjin (local language), Kiswahili and English language depending on respondent preference. Data for this study was collected by trained research assistants who administered the questionnaire using the Computer Assisted Personal Interviewing (CAPI) method whereby data is aggregated in the survey platform on Open Data Kit (ODK). CAPI has numerous benefits including quicker turnaround time as it integrates data collection, data entry, editing coding and cleaning into a single process. In addition, it improves data quality and reduces the researchers stress.

\subsection{Piloting of data collection instruments}

The questionnaires and interview schedules were pretested on 32 farming household heads randomly selected from Kesses sub-county in Uasin Gishu. This helped in identifying unforeseen limitations that could negatively affect the research findings.

\subsection{Validity and reliability of data collection instruments}

Taherdoost, (2016), defines validity as measuring what is intended to be measured. Validity was enhanced through evaluation of the research tools and verification by the researcher in consultation with research supervisor checking whether it covered the purposes of the research and the supervisors input were incorporated into the final questionnaire. Taherdoost, (2016) defines reliability as the extent to which results are consistent. The reliability of the questionnaire items was tested using Cronbach Alpha coefficient $\alpha$, accepted a minimum coefficient of $\geq 0.70$. Cronbach Alpha is the most appropriate measure of reliability when using Likert scales, which were largely employed in this study.

\subsection{Data Analysis and presentation}

The data was analysed using the Statistical Package for Social Sciences (SPSS version 23). The data was analysed both quantitatively and qualitatively using descriptive and inferential statistics. Frequency tables and percentages were used to present the socio-economic characteristics and the agricultural livelihood activities. The descriptive measures are mainly from data on respondent household characteristics such as age, gender and education level; among others. The analysis of variance (ANOVA) F-test was used to test the significance of the overall model with a confidence level of $95 \%$. Ordinal logistic regression was carried out to explain the relationship between the dependent variable and the independent variables. The selection of this analysis was informed by the ordinal nature of the responses.

The logistic regression model is as presented below:

$\mathrm{Y}=\mathrm{b} 0+\mathrm{b} 1 \mathrm{X} 2+\mathrm{b} 2 \mathrm{X} 2+\ldots \ldots \mathrm{bpXp}$ 
Where $\mathrm{Y}$ is the expected state of smallholder food security, $\mathrm{X} 1$ through to $\mathrm{Xp}$ are the independent variables, b0 is the value of $\mathrm{Y}$ when all the independent variables (X1 to Xp) are equal to zero, and b1 through bp are the coefficients to be estimated. The study adopted a limit of 0.05 statistical significance level, with the hypotheses being rejected when the value of its statistics is equal to or less than significance level.

The analysis employs multiple logistic regression to identify relationships among variables. The results are reported in odds ratios (OR), which are calculated by exponentiating the variables coefficients. This measure tells the expected change in the odds ratio of food security for each unit increase in each variable. A logistic model provides a better fit to the data if it demonstrates an improvement over the intercept- only model (null model). The test of hypothesis is based on the Likelihood Ratio Test and Pearson Chi-Square statistic Test. The H0 holds that the null model is true and a $\mathrm{P}$ value for the overall model fit that is less than 0.05 .

\subsection{Ethical consideration}

Approval to carry out the research was sought from University of Eldoret and the County Department of Agriculture and the ward administrators. Sampled participants were allowed to participate voluntarily. Further, the participants were informed about the purpose of the study and that their confidentiality was guaranteed by not including their names in the questionnaires and interview schedules.

\section{RESULTS}

\subsection{Demographic Information of Respondents}

Majority of respondents were male (56\%), with an average age of 38 years and most of them (78\%) married. One hundred and seventy-one (43\%) respondents had secondary school as their highest level of education. In relation to gender of head of households, the majority were led by men, at $78 \%$. More details are provided in Table 1.

Table 1: Smallholder Farmers' Demographic Information

\begin{tabular}{lll}
\hline Indicators & Frequency & Percentage
\end{tabular}

\begin{tabular}{lll} 
Gender & & \\
Male & 222 & 56 \\
Female & 175 & 44 \\
Marital status & & \\
\hline
\end{tabular}


International Journal of Agriculture and Environmental Research

ISSN: 2455-6939

Volume: 06, Issue: 02 "March-April 2020"

\begin{tabular}{lll}
\hline Married & 312 & 78 \\
Divorced/separated & 32 & 8 \\
Widow/widower & 22 & 6 \\
Single & 31 & 8 \\
Education level & & \\
Primary & 106 & 27 \\
Secondary & 171 & 43 \\
Tertiary & 120 & 30 \\
Head of household & & \\
Male & 311 & 78 \\
Female & 86 & 22 \\
\hline
\end{tabular}

$\mathrm{N}=397$. Source: Survey Data, 2018

\subsection{Farm Characteristics of Respondents}

A large proportion of the households (67\%) have farm size below five acres while only (13\%) have above 11 acres. The households' average farm size was reported to be 2.29 acres. Majority, $91 \%$, of the respondents owned the land with only $9 \%$ indicating that they leased land. $69 \%$ have more than six years farming experience (Table 2).

Table 2: Respondent Farm Characteristics

\begin{tabular}{lll}
\hline Variables & Frequency & Percentage \\
\hline Size of farm & & \\
$<=5$ acres & 268 & 67 \\
6-10 acres & 79 & 20 \\
$>=11$ acres & 50 & 12 \\
Land ownership & & \\
Farm owner & 363 & 91 \\
Tenant & 34 & 9 \\
Years of farming experience & & \\
1-5 years & 124 & 31 \\
More than 5 years & 273 & 69 \\
\hline N = 397. Source: Survey Data, 2018 & &
\end{tabular}

\subsection{Household Source of Food of Respondents}

The respondents sourced their food from different sources with the main source of household food being own farm production at $96.9 \%$ followed by purchased food $77.9 \%$. Few (16\%) 
sourced food from relatives and friends while a small number (1.8\%) relied on government rations for their food supply (Table 3).

Table 3: Sources of Household Food

\begin{tabular}{ll}
\hline Sources of food & Percentage \\
\hline Own farm production & 96.9 \\
Purchased food & 77.9 \\
Supplies from relatives and friends & 16.0 \\
Government ratio & 1.8 \\
\hline $\mathrm{N}=$ 397 Source: Survey Data 2018
\end{tabular}

\subsection{Household Food Security Status}

The respondent's household food security was measured using information obtained from various self-assessed questions on household food security situation, experiences and behaviour that serve to a certain degree as indicators for household food security.

The results from the household self-assessment of their household food security for the past 12 months prior to the field survey showed majority $(70 \%$ of them had not experienced food insecurity with a few (19\%) experiencing occasionally and often (11\%) (Table 4).

\section{Table 4: Dimensions of Food Insecurity}

\begin{tabular}{|c|c|c|c|c|}
\hline \multirow[b]{2}{*}{ Variables } & \multicolumn{4}{|c|}{ Category of Responses } \\
\hline & $\begin{array}{l}1 \\
\%\end{array}$ & $\%$ & $\begin{array}{l}3 \\
\%\end{array}$ & $\begin{array}{l}4 \\
\%\end{array}$ \\
\hline $\begin{array}{l}\text { Not able to eat the kinds of foods } \\
\text { preferred because of a lack of } \\
\text { resources }\end{array}$ & 36 & 34 & 16 & 14 \\
\hline $\begin{array}{l}\text { Worried that the household would } \\
\text { not have enough food }\end{array}$ & 36 & 31 & 25 & 8 \\
\hline $\begin{array}{l}\text { Having to eat a limited variety of } \\
\text { foods due to a lack of resources }\end{array}$ & 42 & 28 & 20 & 10 \\
\hline
\end{tabular}


Having to eat a smaller meal than felt needed because there was not 43.5 24.7

21.6 10.2 enough food Not having food to eat of any kind because of lack of resources

Going a whole day and night without eating anything because 48 there was not enough food N = 397 Source: Survey Data 2018

The results above are combined to construct a multidimensional chart showing the respondent state of categories of the food security in Figure 3 below, based on all the variables assessed.

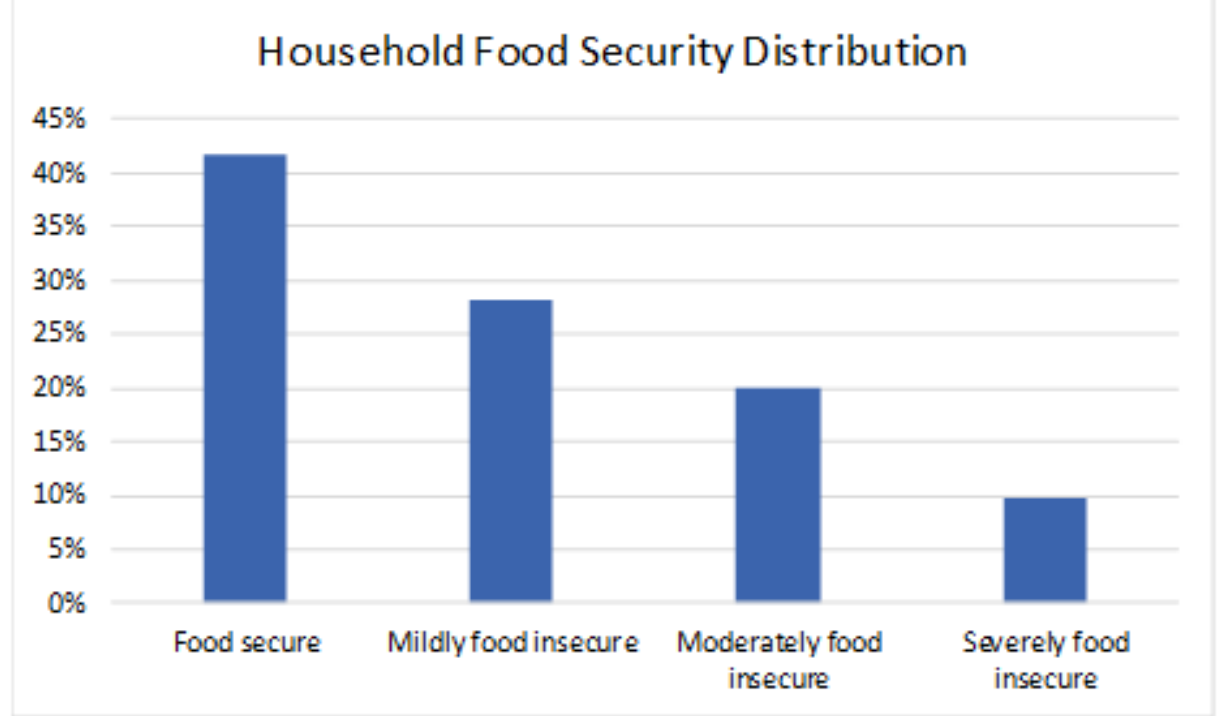

Figure 3: Household food security status

\subsection{Correlation analysis between household food security and demographic characteristics}

Correlation analysis was performed to determine strength of relationships between food security and demographic factors. The results in Table 5 below show a significant positive relationship between gender of the respondents and marital status (rho=0.204). There is also a significant negative relation between gender and age of the respondents and size of farm (rho $=-0.105$ and 0.203 respectively). This shows that gender, marital status and age are likely to affect food shortages. Food insecurity increases depending on gender and marital status while it decreases as age of the households increases. 
International Journal of Agriculture and Environmental Research

ISSN: 2455-6939

Volume: 06, Issue: 02 "March-April 2020"

Table 5: Correlation Analysis between Socio-Demographic Characteristics and Household Food Security

\begin{tabular}{lllllll}
\hline Variable & 1 & 2 & 3 & 3 & 4 & 5 \\
\hline 1. Age & $-.105^{*}$ & 1 & & & & \\
2. Marital & $.204^{* *}$ & $.105^{*}$ & 1 & & & \\
3. Education level & -.018 & $-.240^{* *}$ & -.025 & 1 & & \\
4. Farm size & $-.203^{* *}$ & $.232^{* *}$ & $-.159^{* *}$ & -.091 & 1 & \\
5. Experienced food & .027 & .026 & .061 & .018 & .018 & 1 \\
& shortage \\
** Correlation is significant at 0.01 level (2-tailed) & & & & \\
$*$ Correlation is significant at 0.05 level (2-tailed) \\
$\mathrm{N}=$ 397 Source Survey Data 2018
\end{tabular}

\subsection{Correlation Analysis between Farm Size and Farming Experience and Food Security}

Correlation analysis was performed to determine the strength of relationships between household food security and respondent farm size, ownership and farming experience.

The correlation analysis in Table 6 below shows a significant positive correlation between the type of land ownership and farming experience (rho=0.246). Households who owned land and had more farming years of farming experience are not likely experience food shortages.

\section{Table 6: Correlation Analysis between Farm Size, Farming Experience and Household Food Security.}

\begin{tabular}{llll}
\hline Factors & 1 & 2 & 3
\end{tabular}

\begin{tabular}{llll}
\hline 1. Type of land ownership & 1 & & \\
2. Farming experience & $.246^{* * *}$ & 1 & \\
3. Experience food shortage $\quad .055$ & .083 & 1 \\
\hline ** Correlation is significant at 0.01 level (2-tailed) \\
$\mathrm{N}=$ 397. Source: Survey data 2018
\end{tabular}

\subsection{Ordinal Regression Analysis between Household Food Security and Demographic} Characteristics

The Pearson Chi-square statistics is not statistically significant $p$-value $=0.339>0.05$. The parameter estimates Table 8 below summarizes the effect of each predictor. There is insignificant (p-values>0.05) positive relationship between demographic characteristics and food shortage 
while gender variable shows inverse relationships. The odds of male headed household to experience food insecurity decreases by $1.9 \%$ compared to their female headed counterparts, $(\beta=-0.019)$. The odds for the married head of household to experience food shortages is 0.39 compared to single, widowed, separated combined $(\beta=0.390)$. The odds that those who are illiterate to be exposed to food insecurity is 0.121 as compared to those with some level of education $(\beta=-0.121)$. Furthermore, the odds to experience food shortages for those with less than two acres of land is 0.233 as compared to those with greater than two acres, $(\beta=0.233)$.

$$
y=0.233 x_{1}+0.121 x_{2}+0.39 x_{3}-0.019 x_{4}+0.153
$$

In conclusion, demographic characteristics like gender, marital status, education level and size of farm influence the state of household food security though not significantly as shown in Table 7 below.

\section{Table 7: Ordinal Regression Analysis between Demographic Characteristics and Household Food Security}

\begin{tabular}{llll}
\hline Parameter & & Estimate $(\beta)$ & Sig. \\
\hline Threshold & [frequency of food satisfaction= 0$]$ & .153 & .946 \\
Location & Gender respondent $\left(\mathrm{x}_{4}\right)$ & -.019 & .981 \\
& Marital status $\left(\mathrm{x}_{3}\right)$ & .390 & .562 \\
& Education level $\left(\mathrm{x}_{2}\right)$ & .121 & .700 \\
& Farm size $\left(\mathrm{x}_{1}\right)$ & .233 & .544 \\
\cline { 2 - 3 }
\end{tabular}

Model Chi-Square $=114.551 \quad$ Chi-square $=.371$

Nagelkerke's $\mathrm{R}^{2}=0.013 \quad$ Significance $=.339$

Cox and Snell's $\mathrm{R}^{2}=0.007$

McFadden's $\mathrm{R}^{2}=0.009$

Source: Survey Data 2018

\subsection{Ordinal Regression Analysis between Household Food Security and Household Farming Characteristics}

The Pearson Chi-square statistics is not significant $\mathrm{p}$-value $=0.341>0.05$. The parameter estimates table below summarizes the effect of each predictor. There is insignificant ( $p$ values $>0.05$ ) positive relationship between agricultural activities and its effect on food insecurity while farm record keeping shows an inverse relation. The odds of those who owns land to be exposed to food insecurity is 0.555 compared to tenants $(\beta=-0.555)$. The odds that those with farming experience of between one to five years to experience food insecurity is 0.614 as compared to those with more than five years farming experience $(\beta=0.614)$. 


$$
y=0.555 x_{1}+0.614 x_{2}-0.713
$$

In conclusion, agricultural factors like type of land ownership, farm size and farming experience influence the state of household food security even though not significant as seen in Table 8 below.

\section{Table 8: Ordinal Regression Analysis between Farming Characteristics and Household Food Security}

\begin{tabular}{llll}
\hline Parameter & & Estimate $(\boldsymbol{\beta})$ & Sig. \\
\hline Threshold & [Household food security $=0]$ & -.713 & .745 \\
Location & Type of land ownership $\left(\mathrm{x}_{1}\right)$ & .555 & .522 \\
& Farming experience $\left(\mathrm{x}_{2}\right)$ & .614 & .173 \\
\cline { 2 - 4 }
\end{tabular}

Model Chi-Square $=14.479$

Chi-square $=.341$

Nagelkerke's $R^{2}=0.017$

Significance $=.310$

Cox and Snell's $\mathrm{R}^{2}=0.009$

McFadden's $\mathrm{R}^{2}=0.012$

Source: Survey Data 2018

\section{DISCUSSION}

\subsection{Household Demographic and Farm Characteristics of Respondents}

The demographic and farm characteristics considered for this study included: age, gender of the household head, education, farming experience, farm size, membership to an agricultural cooperative and farmer group. In this study, these variables were found to have an influence on the household food security though not significant. Age can be considered as an indicator for farm experience, it is generally agreed that the probability of a household being food secure increases with the age and the farming experience of the household head.

These results are in line with results from a study in Ethiopia by Agidew \& Singh, (2018) and another by Bashir et al., (2012) in Pakistan, which reported that higher age and farming experience of the household head increases the probability of a household being food secure. It goes further to conclude that the higher the age of the household head, the more stable the economy of the farm household related to the greater farming experience and better access to land compared to younger heads who must wait for land allocation from their families.

The findings indicated that more male than female respondents acquired agricultural extension knowledge for their agricultural activities; likewise, more male respondents used agricultural extension knowledge to improve agricultural production. This disparity is reported in other studies, (Doss, Summerfield, \& Tsikata, 2014; Kiptot, Franzel, \& Degrande, 2014; Villarreal, 
International Journal of Agriculture and Environmental Research

ISSN: 2455-6939

Volume: 06, Issue: 02 "March-April 2020"

2015) commenting on gender disparities in land access and ownership affecting ability to reach full potential in agriculture especially for women. Some of the barriers to achieving gender equality is existing social and cultural norms such as marital status and age which sets outs their role on agriculture and hence their food security (Agarwal, 2012). The study indicated that higher age and farming experience of the household head increases the probability of a household being food secure. In another study by Chiputwa et al., (2011), age had a positive effect on adoption of farm technologies. It indicated that older farmers had experience in beneficial technologies and therefore are quick to adopt new technologies.

Access to agricultural knowledge was influenced by respondents' level of education. Education is positively associated with increased access and utilization of agricultural extension services. Findings indicated that all farmers with informal education mentioned to have been using agricultural extension agents as their source of agricultural knowledge; most of those with primary level of education indicated that they had been using demonstration plots. For this observation, it is expected that the higher level of education enhances the individual's access and utilization of technical information passed on by the extension service providers and that educated households have a high probability of engaging in non-farm related practices, and thus may have cash to purchase food. This result is to a similar study by Ugochukwu \& Phillips, (2018) who reports a significant influence of education in the adoption of new technologies.

Study findings revealed that $67 \%$ of the households interviewed owned less than five acres of land. This is in line with many other reports on the size of land owned by small holder farmers (Jayne, Mather, \& Mghenyi, 2010) which on average is 1.16 acres. Size of the land from the estimation shows it influence food security. Size of land can be considered a proxy for wealthrelated household variables with a direct link to food security. The years of experience in farming shows that $69 \%$ had more than six years, experience goes along with skill acquisition important for improving farm productivity (Chambo, 2009). Marital status was statistically positively associated with household food security. The negative association can be explained by the fact that with marriage arises the possibility of children and other extended family who increase family labour.

Land ownership is positively associated with food security. Ownership allows farming households to make long-term investments to improve farm productivity such as application of soil replenishments and crop rotation. A study carried out by Muraoka, Jin, \& Jayne, (2017), in Kenya also came up with similar results. They found a strong positive association between land ownership and food security and that land productivity tended to be lower for leased plots with farmers making little investment towards improving the quality of the farm. Whereas, land lease 
International Journal of Agriculture and Environmental Research

ISSN: $2455-6939$

Volume: 06, Issue: 02 "March-April 2020"

markets can be a solution for poor households to access cultivation spaces, they do not allow rentals for long term investments as the right to lease solely lies with the landowner.

The farming experience of the farming household shows a positive association with food security. This is similar to other studies linking the farmers farming experience with increase in knowledge and skills on improving farmer's productivity, (Ngele, Arusei, \& Saina, 2015). However, Adejobi, (2006) gives a different opinion, that farming experience can have positive or negative effect, the positive effect would be to a certain period after which the farming experience may have a negative effect especially as the farmer ages.

\subsection{Respondents Household Food Security Situation}

Considering the multidimensionality of food security as defined by the World Food Summit, (1996), a modified form of food security measurement was adopted for this study. To assess the food security situation among the respondents' households; a household level measure was used based on several questions. The questions capture different aspects of food insecurity. This allows for classification of respondents onto different levels of food situations. To avoid the influence of seasonal effects, the state of food security measurement covered the last 12-months prior to the survey.

From the results, it was established that $10 \%$ of the households surveyed were food insecure in the 12 months prior to the survey thus September 2017 to October 2018. Many households (90\%) did not change their consumption patterns in the period with most of them reporting to have taken three meals even though the means many not necessarily be adequate in quality and quantity.

From the inferential analysis, it is observed that those with no utilization of extension services are $65 \%$ likely to be exposed to food insecurity, while the risk of food insecurity for those who reported extension services being useful decreases by 51.3\% compared to those who think otherwise. These results are similar with other studies that have reported extension services influence on the state of household food security but not significantly.

Studies have mixed results on the impact of extension and improved productivity. They reckon that extension impacts are difficult to show because of attribution issues. There are many factors that affect farmer's agricultural performance leading to difficulty in quantifying the cause and effect (Anderson, 2008). (Birkhaeuser et al., (1991) review of extension studies found that 36 studies out of 48 showed significantly positive effects on knowledge, adoption and productivity.

This study showed an insignificant relationship between availability and utilization of agricultural extension and respondent household food security. Generally, almost all smallholder 
International Journal of Agriculture and Environmental Research

ISSN: 2455-6939

Volume: 06, Issue: 02 "March-April 2020"

farmers involved in the study required and acquired agricultural extension knowledge related to different agricultural activities. They required capacity and knowledge for value addition to their agricultural produce. Most smallholder farmers appreciated the fact that the usage of agricultural knowledge increased agricultural production thus improving their livelihoods. It was also evident that smallholder farmers are able evaluate extension services based on adequacy, availability, and timeliness.

It is acknowledged that other multidimensional factors such as household demographics, high prices of agricultural inputs, diminishing land resources coupled with poor agricultural practices among others affect food security (Wachira, 2014; Kumba, 2015).

\section{CONCLUSION AND RECOMMENDATIONS}

From the study finding, majority $30 \%$ of households in Soy and Turbo subcounty were food insecure. The food insecurity status was found to be greatly influenced by household size, age of household heads, marital status and levels of education of family members. The study therefore recommends involvement of all members of the family. This will enhance joint decision-making, increased knowledge retention and greater uptake. Increase investment in agricultural extension service, this is through enhanced training in emerging technologies and issues including climate change as well as enhancing the competence and motivation of the existing ones. This also involves promoting the private extension providers, promote integration of food security and nutrition into agricultural extension services policy to maximize the positive role that agricultural plays in food security, with an aging farming population, promote youth initiatives including access to agricultural services including finance to develop their capacity and facilitate access to land and resources to enable them to engage in agriculture and lastly, embrace use of information technology and other emerging farmer facing approaches such as use of extension call centres which has the potential to cut the costs of extension.

\section{REFERENCES}

Adejobi, A. J. C. U. J. H. and A. O. (2006). Determinants and Measurement of Food Iinsecurity in Nigeria: Some Empirical Policy Guide, 1-15.

Agarwal, B. (2012). Food Security, Productivity and Gender Inequality.

Agidew, A. A., \& Singh, K. N. (2018). Determinants of food insecurity in the rural farm households in South Wollo Zone of Ethiopia: the case of the Teleyayen sub- watershed.

Anderson, J. R. (2008). BACKGROUND PAPER FOR THE WORLD DEVELOPMENT REPORT 2008 Agricultural Advisory Services. 
International Journal of Agriculture and Environmental Research

ISSN: 2455-6939

Volume: 06, Issue: 02 "March-April 2020"

Chiputwa, B. A. S. L. \& P. W. (2011). Adoption of Conservation Agriculture Technologies by Smallholder Farmers in the Shamva District of Zimbabwe: A Tobit application.

Brown, M. E. (2015). Satellite remote sensing in agriculture and food security assessment. $\begin{array}{llll}\text { Procedia Environmental } & \text { Sciences, } & \text { 29(Agri), }\end{array}$ https://doi.org/10.1016/j.proenv.2015.07.278

Burchi, F., \& Muro, P. De. (2015). From food availability to nutritional capabilities : Advancing food security analysis. JOURNAL OF FOOD POLICY. https://doi.org/10.1016/j.foodpol.2015.03.008

Chagomoka, T., Unger, S., Drescher, A., Glaser, R., \& Marschner, B. (2016). Food coping strategies in northern Ghana. A socio - spatial analysis along the urban - rural continuum. Agriculture \& Food Security, 1-18. https://doi.org/10.1186/s40066-0160052-x

Chambo, A. S. (2009). Agricultural co-operatives: Role in Food Security and Rural Development.

Chege J.M, Lemba J.K, S. P. . \& M. E. (2016). Influence of Household Characteristics on Food Security Status of Smallholder Influence of Household Characteristics on Food Security Status of Smallholder Farmers in Kilifi, (August). https://doi.org/10.9734/AJAEES/2016/26845

Dean Birkhaeuser, R. E. E. \& G. F. (1991). The Economic Impact of Agricultural Extension : A Review, 39(3), 607-650.

Doss, C., Summerfield, G., \& Tsikata, D. (2014). Land , Gender , and Food Security, (October), 37-41. https://doi.org/10.1080/13545701.2014.895021

FAO. (2003). Trade Reforms and Food Security: Conceptualizing the linkages.

GoK. (2010). Government of Kenya Kenya Food Security Steering Group ( KFSSG ).

Jayne, T. S., Mather, D., \& Mghenyi, E. (2010). Principal Challenges Confronting Smallholder Agriculture in Sub-Saharan Africa. World Development, 38(10), 1384-1398. https://doi.org/10.1016/j.worlddev.2010.06.002

Jensen, H. H. (2016). Agricultural \& Applied Economics Association Food Insecurity and the Food Stamp Program Author (s): Helen H . Jensen Source: American Journal of Agricultural Economics, Vol . 84, No. 5, Proceedings Issue Published by: Oxford 
International Journal of Agriculture and Environmental Research

ISSN: 2455-6939

Volume: 06, Issue: 02 "March-April 2020"

University Press on behalf of the Agricultural \& Applied Economics Association Stable URL: http://www.jstor.org/stable/1245051 FOOD INSECURITY AND THE FOOD STAMP PROGRAM, 84(5), 1215-1228.

Khalid, M., Schilizzi, S., \& Pandit, R. (2012). The Determinants of Rural Household Food Security for Landless Households of the Punjab, Pakistan.

Kiptot, E., Franzel, S., \& Degrande, A. (2014). ScienceDirect Gender, agroforestry and food security in Africa. Current Opinion in Environmental Sustainability, 6, 104-109. https://doi.org/10.1016/j.cosust.2013.10.019

Kumba, J. K. (2015). The Role of Household Characteristics in Determining Food Security in Kisii Central Sub-County, Kenya, 5(7), 186-194.

Lowder, S. K., Skoet, J., \& Raney, T. (2016). The Number, Size, and Distribution of Farms, Smallholder Farms , and Family Farms Worldwide q. World Development, 87, 16-29. https://doi.org/10.1016/j.worlddev.2015.10.041

Mensah, O. (2018). Determinants of Household Food Security in the Sekyere-A fram Plains District of Ghana, (June).

Misselhorn, A. A. (2005). What drives food insecurity in southern Africa? a meta-analysis of household economy studies, 15, 33-43. https://doi.org/10.1016/j.gloenvcha.2004.11.003

Muraoka, R., Jin, S., \& Jayne, T. S. (2017). Land Use Policy Land access, land rental and food security: Evidence from Kenya. Land Use Policy, (October), 0-1. https://doi.org/10.1016/j.landusepol.2017.10.045

Murphy, S. (2012). Changing Perspectives : Small-scale farmers, markets and globalisation.

Ngele, M. J., Arusei, E., \& Saina, C. (2015). Socio-Economic Factors Influencing Farmers' participation in Demand driven extension services among small scale farmers: A Case of National agriculture and livestock extension programme (NALEP) In Moiben, Uasin Gishu County, Kenya, 547-551.

Niles, M. T., \& Brown, M. E. (2017). A multi-country assessment of factors related to smallholder food security in varying rainfall conditions. Scientific Reports, (May), 1-11. https://doi.org/10.1038/s41598-017-16282-9

Rapsomanikis, G. (2015). The economic lives of smallholder farmers. Food and Agriculture Organization of the United Nations Rome. 
Summit, W. F. (1996). World Summit on Food Security, (November 2009), 16-18.

Taherdoost, H., Business, H., Sdn, S., Group, C., \& Lumpur, K. (2016). Validity and Reliability of the Research Instrument; How to Test the Validation of a Questionnaire/Survey in a Research, 5(3), 28-36.

Tioko, L. A. (2015). Food insecurity status at household level in Kamukunji estate, Logiron Augustine Tioko PhD in Sociology (Ongoing) Masters Degree in Arts (Community Development option) Bachelors Degree in Arts, 4(4), 8-12.

Ugochukwu, A. I., \& Phillips, P. W. B. (2018). Technology Adoption by Agricultural Producers: A Review of the Literature, 361-377.

Villarreal, M. (2015). Decreasing Gender Inequality in Agriculture : Key to Eradicating Hunger, $x x(1)$.

Vorley, B., \& Chan, M. (2012). TIPPING THE, (December).

Wachira, K. (2014). Adoption of E-Business by Small and Medium Enterprises in Kenya: Barriers and Facilitators, 4(11), 177-187. https://doi.org/10.6007/IJARBSS/v4-i11/1293

Wachira, W. F. (2013). Rainwater harvesting practices, cropping systems and productivity in smallholder farms in Laikipia central district.

Wiggins, S., Argwings-kodhek, G., Leavy, J., \& Poulton, C. (2011). Small farm commercialisation in Africa: Reviewing the issues, (April). 